\title{
Latency- and Defense-Related Ultrastructural Characteristics of Apple Fruit Tissues Infected with Botryosphaeria dothidea
}

\author{
Ki Woo Kim, Eun Woo Park, Young Ho Kim, Kyung-Ku Ahn, Pan Gi Kim, and Kyung Soo Kim
}

\begin{abstract}
First, second, and third authors: School of Agricultural Biotechnology, Seoul National University, Suwon 441-744, Korea; fourth and fifth authors: National Instrumentation Center for Environmental Management, Seoul National University, Suwon 441-744, Korea; and sixth author: Department of Plant Pathology, University of Arkansas, Fayetteville 72701.
\end{abstract}

Accepted for publication 23 October 2000.

\begin{abstract}
Kim, K. W., Park, E. W., Kim, Y. H., Ahn, K.-K., Kim, P. G., and Kim, K. S. 2001. Latency- and defense-related ultrastructural characteristics of apple fruit tissues infected with Botryosphaeria dothidea. Phytopathology $91: 165-172$.

Apple fruit tissues infected with Botryosphaeria dothidea were examined by transmission electron microscopy using susceptible cv. Fuji and resistant cv. Jonathan. Immature (green) and mature (red) fruits of cv. Fuji with restricted or expanding lesions were also examined to reveal subcellular characteristics related with latent and restricted disease development. In infected susceptible mature fruits, cytoplasmic degeneration and organelle disruption commonly occurred, accompanying cell wall dissolution around invading hyphae. Cell wall dissolution around invading hyphae in subepidermis was rare in immature, red halosymptomed cv. Fuji and resistant cv. Jonathan fruits. In infected im-
\end{abstract}

ABSTRACT mature fruits of cv. Fuji, presumably at the latent state of disease development, cellular degeneration was less severe, and invading hyphae contained prominent microbody-lipid globule complexes or the deposition of thin electron-dense outer layer around cell wall of intercellular hyphae. Both mature fruits with red halos and resistant apple fruits formed cell wall protuberances at the outside of cell walls. In addition, electron-dense extramural layers were formed in the resistant apple fruits. Aberrant hyphal structures such as intrahyphal hyphae were found only in resistant fruit tissues, indicating the physiologically altered fungal growth. These ultrastructural changes of host tissues and fungal hyphae may reflect the pathogenesis of apple white rot under varying conditions of apple fruits.

Additional keywords: glyoxysomes, latent infection, Malus domestica, wall appositions.
White rot is one of the most destructive diseases of apple (Malus domestica Borkh.) in the world (33). The disease results in fruit rot and extensive cankers on limbs, eventually resulting in tree death. The causal organism is an ascomycetous fungus $B o$ tryosphaeria dothidea Ces. \& de Not. (synonymous with $B$. ribis Grossenb. \& Dug.), anamorph Fusicoccum aesculi Corda (33). B. dothidea is found in most tropical and warm temperate regions as a pathogen of many economically important crops and woody plants (23). The fungus has been reported to enter apple fruits through natural openings, such as lenticels or surface cracks, or wounds possibly caused by insects, and to form dome-shaped appressoria on the fruit surface (14).

The main inoculum of $B$. dothidea is conidia, which are found in orchards throughout the growing season of apple trees $(15,34)$. Typical soft and light-colored rot symptoms appear mostly on mature red fruits and may expand throughout whole fruits. Symptoms usually become noticeable 6 to 8 weeks before harvest (33). However, fruits can be infected by conidia within 7 weeks after petal fall (26). Latent infection should undergo during the immature stage of apple fruits. The latent infection is related with several host factors such as phenolic compounds, soluble sugars, $\mathrm{pH}$, fruit acids, and amino acids in apple fruits $(12,17,32)$. It is generally accepted that fungitoxic compounds in immature fruits, including phytoalexins and benzoic acid, and fruit substrates unfavorable to fungal growth are responsible for suppressing fungal invasion and delaying symptom appearance in immature fruits $(1,17,30)$.

Corresponding author: E. W. Park; E-mail address: ewpark@ plantpath.snu.ac.kr

Publication no. P-2000-1127-01R

(c) 2001 The American Phytopathological Society
Different levels of resistance to the white rot have been reported among various apple cultivars (16). Restriction of disease development in the field was found in susceptible apple fruits as well as resistant ones. In susceptible mature fruits, small circular lesions surrounded by red halos are occasionally found on naturally infected apple fruits with $B$. dothidea (33). The lesion surrounded by the halo usually cannot keep expanding, and become harder than other parts of the fruit, which may be a defense-related response. In resistant fruits, the initial morphological characteristics of lenticels or parenchyma tissues beneath the epidermis, and phenolic compounds of apple fruits were suggested to be basic features of resistance. However, it is unclear whether any subcellular defense mechanisms are involved in resistance to the white rot.

Initial symptoms of the disease are circular brown lesions on the fruit surface, but symptom development differs among susceptible and resistant apple fruits. Histopathological studies have been conducted on $B$. dothidea in several hosts by light microscopy $(2,11,29)$. However, subcellular aspects of host responses to fungal infection and their relation to latency and resistance have been little studied in apple fruits. Therefore, this study was conducted to examine the ultrastructural characteristics of latency of symptom expression and differences in disease resistance between apple cultivars. Mature and immature susceptible fruits, red halosymptomed susceptible fruits (with restricted symptom development), and resistant fruits were compared in the subcellular modifications of the infected apple fruit tissues.

\section{MATERIALS AND METHODS}

Inoculum preparation. An isolate of $B$. dothidea (BD-3) was obtained from a naturally infected apple fruit showing typical white rot symptoms. The isolate was grown on freshly prepared 
acidified ( $\mathrm{pH} 4$ to 5) potato-sucrose agar amended with streptomycin sulfate at $100 \mu \mathrm{g} / \mathrm{ml}$ to inhibit bacterial contamination. Barley grain media were prepared for inoculum production as previously reported (13). Briefly stated, $20 \mathrm{~g}$ of barley (Hordeum vulgare L.) grains were immersed with $12 \mathrm{ml}$ of distilled water in 250-ml Erlenmeyer flasks overnight. They were autoclaved at the pressure of $2 \mathrm{kgf} / \mathrm{cm}^{2}$ for $1 \mathrm{~h}$, which was repeated on the following day. The media were inoculated with two 5-mm diameter mycelial plugs of $B$. dothidea, and incubated at $25^{\circ} \mathrm{C}$ under continuous fluorescent light for 1 week. The flasks were occasionally shaken to prevent caking of the grains. Pycnidia were produced on the barley grains 3 days after inoculation. Two weeks after inoculation, conidia were dislodged by flooding the inoculated barley grains with sterilized distilled water. The suspension was filtered through two layers of cheesecloth to remove mycelial fragments. The inoculum concentration was adjusted to $1.0 \times 10^{5}$ conidia per ml using a hemacytometer.

Preparation of infected fruits. Four types of apple fruits infected with $B$. dothidea were prepared, respectively, as follows; red fruits (80-mm diameter) of cv. Fuji as susceptible mature fruits (sample 1), green fruits (25-mm diameter) of cv. Fuji as susceptible immature fruits (sample 2), mature cv. Fuji fruits with red halo symptoms (sample 3), and red fruits (65-mm diameter) of cv. Jonathan as resistant mature fruits (sample 4). Infected tissues from samples 1,2 , and 4 were prepared by artificial inoculation. The fruits were washed with mild detergent to remove dirt, insect honeydew, and pesticide residues. Prior to inoculation, the fruits were surface-sterilized with $0.1 \%$ sodium hypochlorite solution for $2 \mathrm{~min}$, rinsed with sterilized distilled water, and allowed to air dry for $30 \mathrm{~min}$. Four to six lenticel regions were circled on each fruit with a marker pen for point inoculations. Drops (approximately $20 \mu \mathrm{l}$ per drop) of the conidial suspension were placed on each inoculation site of the fruits with an adjustable micropipette. Immediately after inoculation, the fruits were placed in a polystyrene box $(32 \times 43 \times 8 \mathrm{~cm})$ lined with moist paper towels, and the box was placed in an incubator at $25^{\circ} \mathrm{C}$ under continuous darkness for 2 weeks. The tissues of brown spot symptoms around the inoculation points were used for specimen preparation for transmission electron microscopy.

For sample 3 , because no such symptoms were induced by the artificial inoculation, naturally infected red fruits of cv. Fuji (susceptible mature fruits) showing red halos were collected from an apple orchard at Suwon, Korea. The red halo tissues were processed for transmission electron microscopy. Naturally infected red fruits of cv. Fuji showing rapidly expanding lesions were also harvested to compare the subcellular characteristics with those of red halos.

Specimen preparation for transmission electron microscopy. Squares of brown lesions of samples 1,2, and 4, and red halos of sample 3 (each $1 \times 1 \mathrm{~mm}$ with approximately $1-\mathrm{mm}$ thickness of underlying tissues) were excised with a sterile razor blade. Uninoculated healthy parts of apple fruits were also excised as a control. Specimens were fixed with modified Karnovsky's fixative consisting of $2 \%(\mathrm{vol} / \mathrm{vol})$ glutaraldehyde and $2 \%$ (vol/vol) paraformaldehyde in $0.05 \mathrm{M}$ sodium cacodylate buffer ( $\mathrm{pH}$ 7.2) overnight, and washed three times with the same buffer for $10 \mathrm{~min}$ each. They were postfixed with $1 \%(\mathrm{wt} / \mathrm{vol})$ osmium tetroxide in the same buffer at $4{ }^{\circ} \mathrm{C}$ for $2 \mathrm{~h}$, and washed twice with distilled water. The postfixed specimens were en bloc stained with $0.5 \%$ uranyl acetate at $4{ }^{\circ} \mathrm{C}$ overnight. They were dehydrated in a graded ethanol series $(30,50,70,80,95$, and $100 \%)$, and three times in $100 \%$ ethanol for $10 \mathrm{~min}$ each. The specimens were further treated with propylene oxide as a transitional fluid two times for $30 \mathrm{~min}$, respectively, and embedded in Spurr's medium. Transverse sections of the fruit subepidermis were made by a diamond knife with an ultramicrotome (MT-X, RMC Inc., Tucson, AZ). Ultrathin sections (approximately $70 \mathrm{~nm}$ thick) were mounted on copper grids, and double-stained with $2 \%(\mathrm{wt} / \mathrm{vol})$ uranyl acetate and with
Reynolds' lead citrate for 7 min, respectively. Sections were examined with a transmission electron microscope (JEM-1010, JEOL Ltd., Tokyo) operated at an accelerating voltage of $80 \mathrm{kV}$. At least three embedded blocks were made for each type of fruit, and more than 10 ultrathin sections per block were examined under the electron microscope.

\section{RESULTS}

Cytopathology of susceptible mature fruits (sample 1). The outer flesh of apple fruit derived from the floral tube is composed of cuticular layers, epidermis, subepidermal collenchyma or hypodermis, and inner ground parenchyma (7). In the transmission electron microscopy of healthy apple fruit tissue, the subepidermal collenchyma, which is the main region colonized by the fungus before full symptom development, exhibited thick-walled collenchyma-like cells with slight secondary wall thickenings and with little intercellular spaces (data not shown). The functional cells contained intact cell organelles such as nucleus, mitochondria, and endoplasmic reticulum. There was no indication of cytoplasmic degradation. However, subepidermal cells of mature cv. Fuji fruits infected with $B$. dothidea were degenerated, showing extensive fungal invasion in the lenticel (Fig. 1A). Some hyphae were located above or on subepidermal cells of the lenticel, whereas others grew intercellularly or intramurally (within cell walls) in subepidermal regions. Electron-lucent areas were formed in host cell walls adjacent to the invading hyphae, indicating the dissolution of the cell walls. Disrupted fibrillar matrix from the cell wall was exhibited around the invading hyphae in middle lamella (Fig. 1B). Cellular degradation was noted in the lenticel region that was invaded extensively by the hyphae, characterized by indiscernible cell organelles such as nucleus and plastids and necrotized cytoplasm (Fig. 1C). The shape of the degraded cell was markedly distorted compared with that of the uninoculated control fruit cells. Intracellular occupation of hyphae was sometimes observed, and the infected cells were degenerated, showing degraded cytoplasm with no discernible cell organelles (Fig. 1D). Electron-dense materials accumulated along the periphery of the central vacuoles.

Subcellular features of the invading hyphae in the mature susceptible fruits exhibited cells with electron-lucent wall, prominent lipid globules (Fig. 1A and C) except a few hyphae located in the middle lamella (Fig. 1B), and dense cytoplasm sometimes containing vacuoles (Fig. 1D). No microbodies or structural aberrations of hyphae were observed in infected susceptible mature fruits.

Cytopathology of susceptible immature fruits (sample 2). Hyphae were commonly found between and inside the subepidermal cells of immature cv. Fuji fruit tissues infected with the fungus 2 weeks after inoculation (Fig. 2). By intercellular or intracellular hyphal invasion, the collenchymatic cells were damaged as indicated by the necrotic cytoplasm containing degenerated cell organelles including nucleus and plastid (Fig. 2A and B) as in susceptible mature fruits. However, unlike the mature fruits, dissolution of the host cell walls was rarely found in the vicinity of hyphae (Fig. 2A).

The cellular features of the invading hyphae were different from those in the subepidermal tissues of the mature fruits. The hyphae outside of host cell walls had electron-lucent cell walls, lipid globules, and dense cytoplasm as in sample 1, but the cell wall was covered with electron-dense materials forming a layer (Fig. 2A). On the other hand, no electron-dense layer was formed around the cell walls of intracellular hyphae; lipid globules and microbodies were abundant and placed in close association with each other, forming microbody-lipid globule complexes (Fig. 2B and $\mathrm{C}$ ). These complexes were frequently found in inter- and intracellular hyphae in the infected susceptible immature fruits. The microbodies contained one or two electron-dense crystalline inclusions. 
Cytopathology of susceptible mature fruits with red halos (sample 3). The major difference in the subepidermal cellular responses of red halo regions from those of brown lesions in samples 1 and 2 was the formation of cell wall protuberances adjacent to invading hyphae (Fig. 3A and B). They were extruded outward into wide or narrow intercellular spaces, sometimes occluding intercellular spaces, in which the hyphae appeared to be hindered in growth, showing the depletion of cytoplasmic contents. However, in the susceptible mature fruits showing rapid symptom expansion, no cell wall protuberances were formed around the invading hyphae in the subepidermal fruit tissues (Fig. 3C). No cytoplasmic depletion of the invading hyphae was noted. As in sample 1, dissolution of the cell wall and middle lamella was exhibited as indicated by the electron-lucent areas around the invading hyphae.

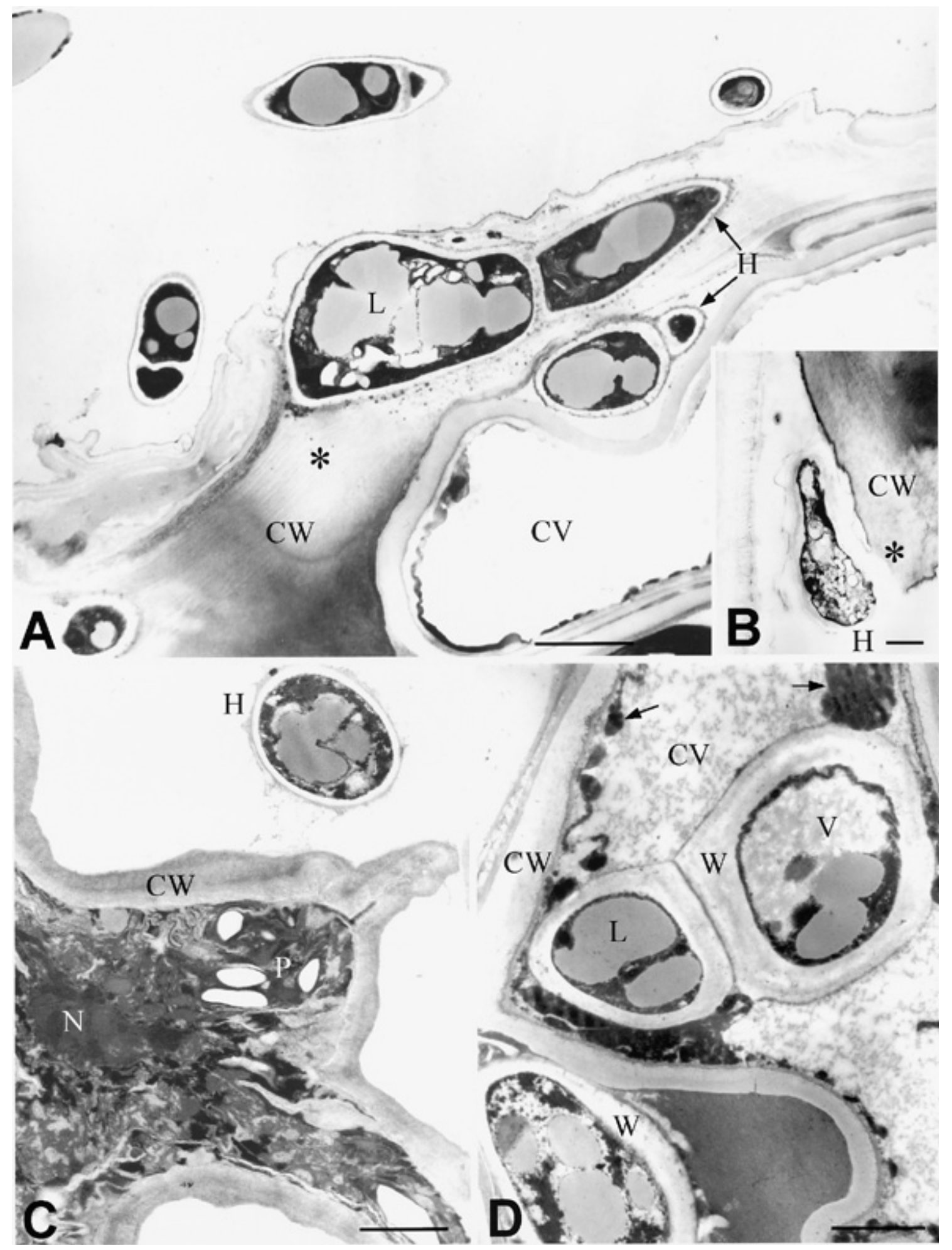

Fig. 1. Transmission electron micrographs of inoculated susceptible mature apple fruits with Botryosphaeria dothidea. A, Lenticel colonization by intercellular or intramural hyphae $(\mathrm{H})$. Dissolution of cell wall $(\mathrm{CW})$ of subepidermal cells indicated by electron-lucent area (asterisk) adjacent to intercellular or intramural hyphae. $\mathrm{CV}=$ host central vacuole; $\mathrm{L}=$ lipid globule; $\mathrm{Bar}=2 \mu \mathrm{m}$. B, Dissolution of middle lamella by an invading hypha $(\mathrm{H})$. Note host cell wall $(\mathrm{CW})$ modification (asterisk) around the hypha. Bar $=1 \mu \mathrm{m}$. C, Host cell degradation in the vicinity of a hypha (H). The host cell exhibits electron-dense cytoplasm apparently due to the condensation of cytoplasmic contents. $\mathrm{N}=$ nucleus; $\mathrm{P}=$ plastid; $\mathrm{Bar}=2 \mu \mathrm{m}$. $\mathbf{D}$, Intracellular growth of hyphae. Arrows indicate accumulation of osmiophilic materials in host central vacuole $(\mathrm{CV}) . \mathrm{V}=$ fungal vacuole; $\mathrm{W}=$ fungal cell wall; $\mathrm{Bar}=2 \mu \mathrm{m}$. 
Cytopathology of resistant mature fruits (sample 4). Hyphal penetration was observed in the epidermal and subepidermal tissues of the resistant mature fruits. Infected epidermal cells were necrotic and degenerated, containing intracellular hyphae (data not shown). In the subepidermal tissues, prominent cell wall protuberances were formed locally or over a wide area of host cell wall adjacent to intercellular hyphae (Fig. 4A) as in the red halo regions of the susceptible mature fruits. The wall protuberances appeared to block the way for the fungal growth by extended wall outgrowth, by surrounding the invading hypha (Fig. 4A) or by occluding intercellular space with wall bridges formed from the neighboring cell walls (Fig. 4B). The outer parts of the wall pro-

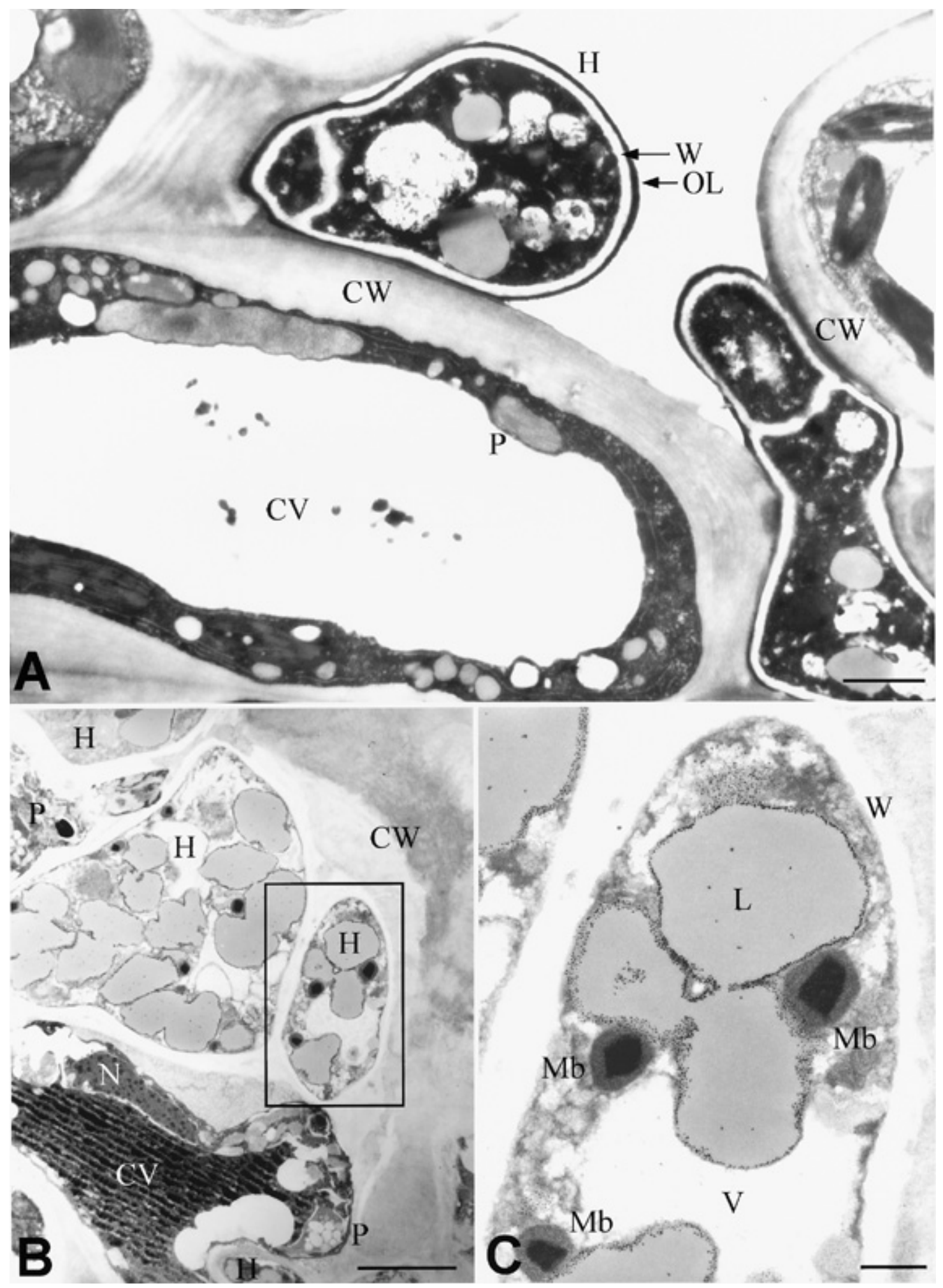

Fig. 2. Transmission electron micrographs of inoculated susceptible immature apple fruits with Botryosphaeria dothidea. A, Subepidermal cells with intercellular hyphae $(\mathrm{H})$. The host cytoplasm is electron-dense (probably necrotizing). The hyphae are in contact with host cell walls (CW), having electrondense outer layer (OL) around the fungal cell wall (W). CV = host central vacuole; $\mathrm{P}=$ plastid; Bar $=2 \mu \mathrm{m}$. B, Subepidermal cells colonized by intracellular hyphae $(\mathrm{H})$. Host cell cytoplasm appears to be necrotizing. $\mathrm{N}=$ nucleus; Bar $=3 \mu \mathrm{m}$. $\mathbf{C}$, Higher magnification of the rectangle of Figure $2 \mathrm{~B}$, showing topographical association of microbodies $(\mathrm{Mb})$ and lipid globules $(\mathrm{L})$ in the intracellular hypha. Crystalline inclusions are found in microbodies. $\mathrm{V}=$ fungal vacuole; $\mathrm{W}=$ fungal cell wall; $\mathrm{Bar}=0.5 \mu \mathrm{m}$. 
tuberance were electron-dense, whereas the inner parts were electron-lucent as normal plant cell wall (Fig. 4A). In addition, electron-dense extramural layers often extended over a wide area of host cell walls that were in the vicinity of intercellular hyphae.
In the resistant fruits, cell wall dissolution (electron-lucent area) around invading hyphae was rarely observed (Fig. 4B), and the infected subepidermal cells were not so extensively destroyed as in the susceptible fruits.
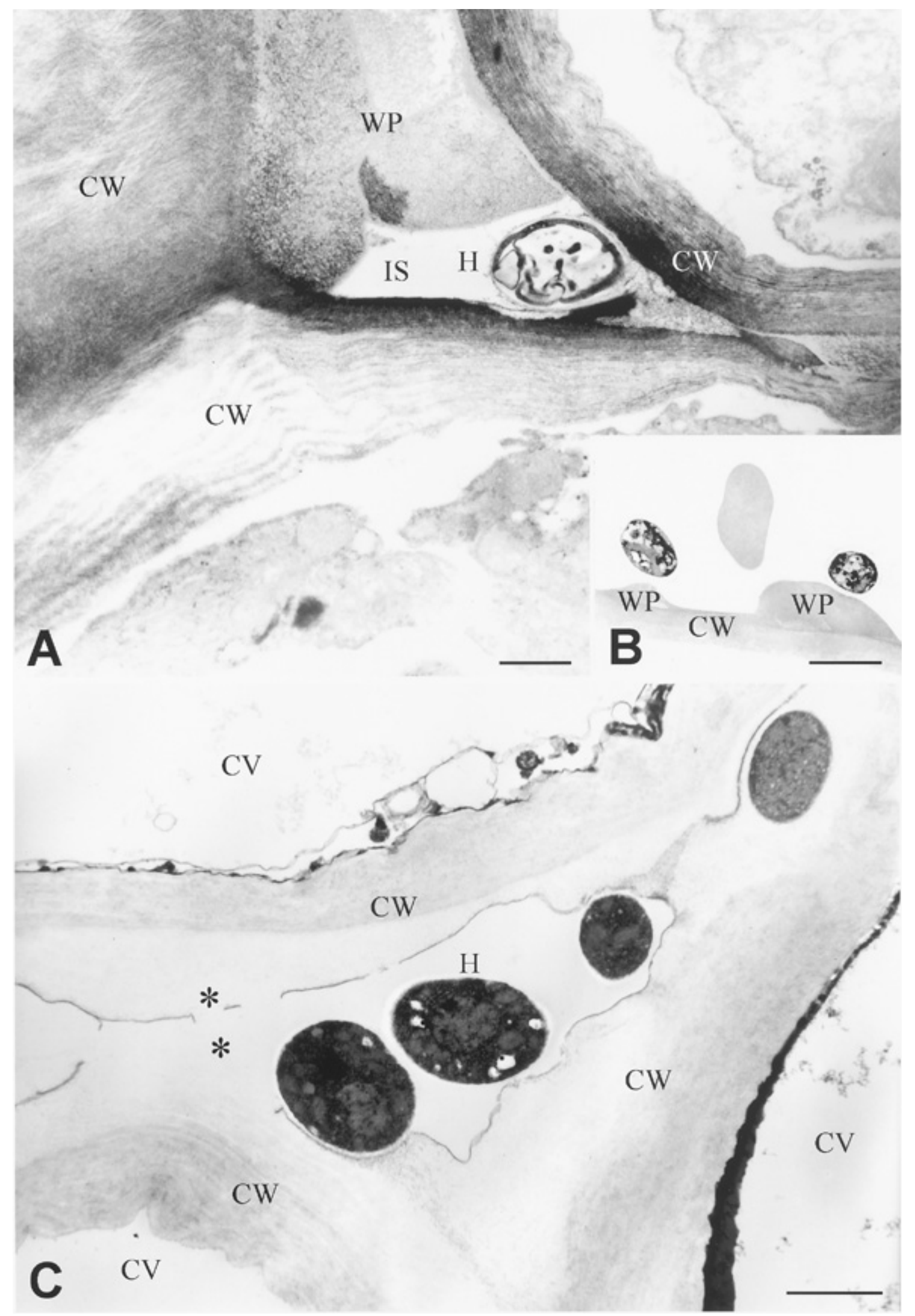

Fig. 3. Transmission electron micrographs of naturally infected apple fruits showing $\mathbf{A}$ and $\mathbf{B}$, red halos around white rot lesions and $\mathbf{C}$, rapidly expanding white rot lesions. A, Occlusion of intercellular space (IS) by a cell wall protuberance (WP). A hypha (H) entrapped in the occluded intercellular space exhibits depletion of cytoplasmic contents. Bar $=1 \mu \mathrm{m}$. B , Cell wall protuberances (WP) adjacent to hyphae on the outer side of host cell wall $(\mathrm{CW})$. Bar $=3 \mu \mathrm{m}$. $\mathbf{C}$, Tissue with a rapidly expanding lesion, showing dissolution of cell wall $(\mathrm{CW})$ indicated by electron-lucent areas (asterisks). $\mathrm{CV}=\mathrm{host}$ central vacuole; Bar $=2 \mu \mathrm{m}$. 
Invading hyphae in the resistant mature fruits were not much different from those in the susceptible fruits; both typically had electron-lucent cell wall and lipid globules. Microbodies associated with lipid globules were occasionally found in hyphal cytoplasm. However, a characteristic hyphal structure was often found in the resistant fruits, termed as intrahyphal hypha that was surrounded by and delimited by electron-lucent cell wall of the enclosing hypha (Fig. 4C). In some instances, a hypha contained several intrahyphal hyphae, and an intrahyphal hypha also contained another intrahyphal hypha (Fig. 4D).

\section{DISCUSSION}

The ultrastructural features of apple fruit tissues infected with $B$. dothidea in this study indicated that the fungus was definitely a facultative parasite that colonizes dying or dead tissues for nutritional uptake. The death of infected fruit cells was commonly found regardless of susceptible or resistant and mature or immature states of apple fruits, although the degree of cellular degeneration varied depending on the states of fruits examined. The cell death itself may not delay or stop the growth of the necrotrophic

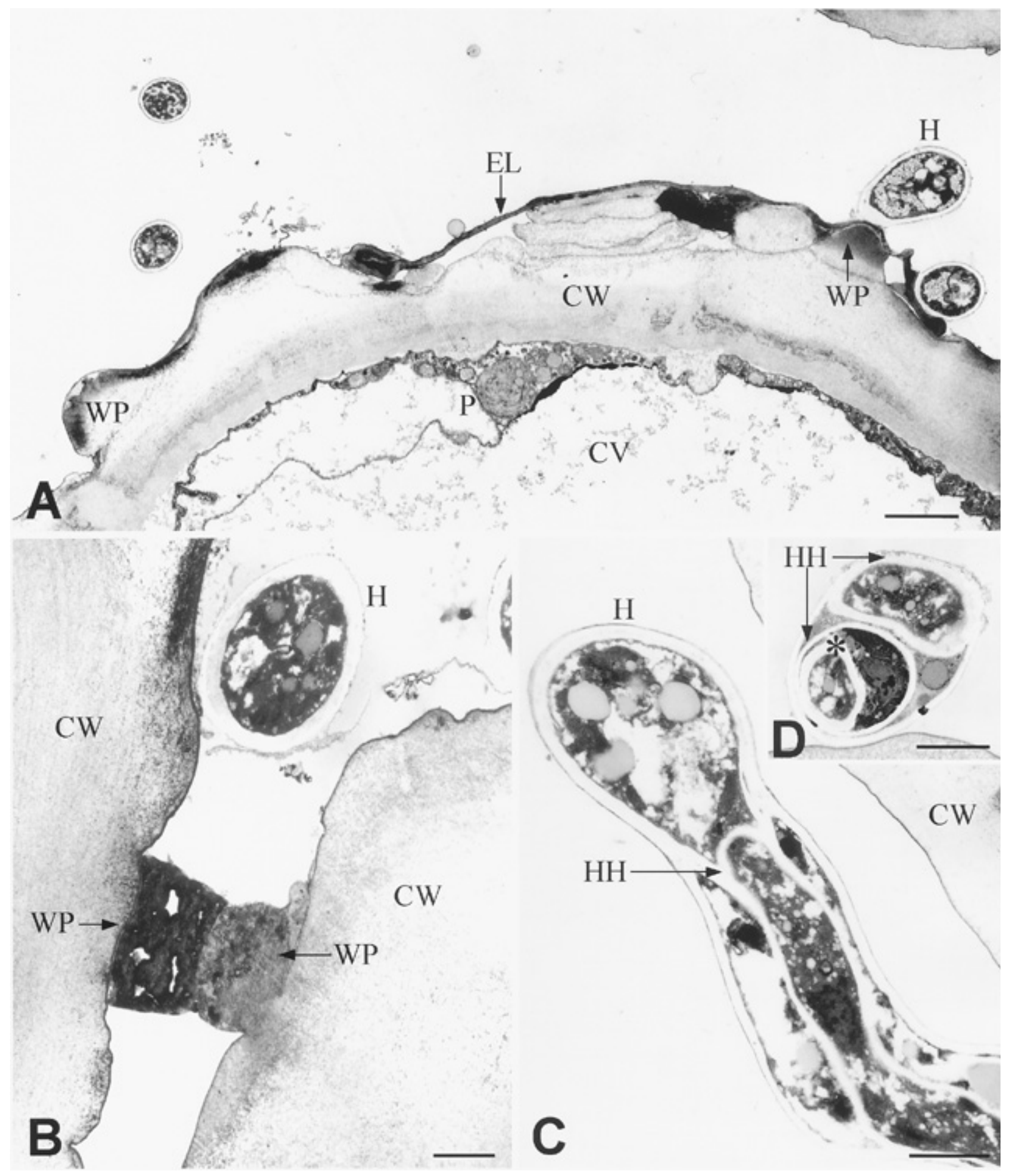

Fig. 4. Transmission electron micrographs of inoculated resistant mature apple fruits with Botryosphaeria dothidea. A, Formation of cell wall protuberances (WP) and extramural layers (EL) on the outside of host cell wall (CW). $\mathrm{CV}=$ host central vacuole; $\mathrm{H}=$ hypha; $\mathrm{P}=$ plastid; Bar $=2 \mu \mathrm{m}$. B, Occlusion of intercellular space by forming a bridge with two cell wall protuberances (WP) from neighboring host cell walls (CW). Bar $=1 \mu \mathrm{m}$. C, Longitudinal section of an intrahyphal hypha $(\mathrm{HH})$ in an intercellular hypha $(\mathrm{H})$. Note a septum within an intrahyphal hypha. Bar $=2 \mu \mathrm{m}$. D, Transverse section of intrahyphal hyphae $(\mathrm{HH})$ in an intercellular hypha. Note an intrahyphal hypha (asterisk) in an intrahyphal hypha. Bar $=1 \mu \mathrm{m}$. 
fungus. Our findings suggest that some biochemical phenomena rather than mere cell death may govern the fungal growth in the different fruit states, modifying ultrastructural characteristics of the hyphae as well as host cells, especially host cell walls.

In susceptible mature fruits with expanding rot symptoms, cell degradation and especially cell wall dissolution around the invading hyphae were prominent. Considering the major components of cell wall and middle lamella, the cell wall dissolution may have occurred due to cellulose- and pectin-degrading enzymes produced in situ, which may diffuse extracellularly from the hyphae (9). The splitting of middle lamella, which is related with tissue softening and thus rot symptom development, may be mostly caused by enzymatic removal of pectins. Several pectolytic enzymes such as exo-polygalacturonase, exo-polymethylgalacturonase, polygalacturonase-trans-eliminase, and pectinmethyltrans-eliminase are produced in apple fruits by B. dothidea (22, $25)$, and cell degradation and cell wall modifications are due to the combined action of these enzymes (24). The fungus grew intercellularly, intracellularly, and intramurally in subepidermal tissues of apple fruits. Cell degradation and cell wall dissolution around the various invading hyphae may lead to expansion of rot symptoms in susceptible mature fruits.

Cell wall dissolution around invading hyphae in subepidermal cells was rare in immature, red halo-symptomed cv. Fuji and resistant cv. Jonathan fruits. In immature cv. Fuji fruits, infected host tissues were also damaged as in mature ones, but not severely. However, the most striking difference in the immature fruit tissues from the mature ones was not noted in the structural modifications of host cells but in the morphology of the invading hyphae, which had prominent microbody-lipid globule complexes. The association of microbodies with lipid globules in the hyphae is structurally very similar to that found in plant seeds, where microbodies (glyoxysomes) are involved in lipid utilization via glyoxylate cycle (10). Microbodies in the fungal hyphae are glyoxysomes and their close association with lipid globules and crystalline inclusions also support their identity $(10,21)$. Crystalline inclusions in glyoxysomes are catalase crystals that degrade hydrogen peroxide produced from lipid metabolism or from host defense-related reactions $(8,10,27,28)$. The above aspects suggest that the fungus in the susceptible immature fruits may be in the latent state of disease development. The fungus stores nutritional materials that can be easily used for its growth when placed under favorable conditions. Field observations of the latent infections in immature fruits support the conclusion that the fungal hyphae can survive fungistatic conditions in immature fruits and resume their host invasion at near harvest.

Another structural feature of the hyphal characteristics in the susceptible immature fruits was the deposition of the thin electron-dense outer layer around the cell wall of the intercellular hyphae. This wall layer may be a reflection of retarded fungal growth or a form of dormant state, because such a structural characteristic was found in nongerminated conidia and associated with limited growth of Cladosporium spp. within tissues of a resistant host $(18,19)$. In immature apple fruits, subepidermal collenchymatic tissues have no or very little intercellular spaces (7) that can inhibit the intercellular fungal growth. Low soluble sugars, low $\mathrm{pH}$, and high antimicrobial substances such as phenolics and acids in immature apple fruits may also retard the fungal growth $(1,12$, 17,32). These physicochemical characteristics of immature apple fruits may be responsible for suppressing fungal invasion and delaying symptom appearance, leading to the latent infection.

Cell wall protuberances were invariably formed in the subepidermal tissues of red halo regions of susceptible cv. Fuji fruits and resistant $\mathrm{cv}$. Jonathan fruits in this study. These structures are outgrowth forms of cell walls that are distinct from papillae formed on the inside of host cell walls (6). The wall protuberances probably deter intra- and intercellular fungal invasion by forming structural barriers with thickening of cell walls and occlusion of intercellular spaces. The fact that the wall protuberances were formed in resistant and susceptible apple fruits only with restricted symptoms suggests that they may not be constitutive or pre-existing but induced by the fungal infection. The formation of wall protuberances is observed in bell pepper fruits (5), scutellum of maize seedlings (24), and also in apple fruits inoculated with other pathogens (6). In addition, electron-dense extramural layers were formed outside of the cell wall protuberances in resistant apple fruit tissues. Their chemical composition was not determined; however, the electron-dense materials may be pectic substances, because the pectic material forms crests or wartlike accumulations in collenchymatic tissues of some plant species (7). The above aspects suggest that their formation may not be induced in a pathogen-specific manner, but may be constitutive depending on apple cultivars or can be induced under certain fruit conditions as defense-related structures.

Intrahyphal hyphae were observed in the intercellular spaces of subepidermal tissues in resistant mature fruits. Because these structures were not found around cell wall protuberances in red halo regions of susceptible fruits, the structural aberrations may not be caused only by the structural defenses. Certain biochemical factors may have been involved in the hyphal morphological modifications. These structures are also formed in other fungi, and are suggested to be survival forms that can be induced under stressed conditions $(3,4,20,31)$. The intrahyphal hyphae may be a form of fungal responses to host resistance to be protected from surrounding stressed environments by the enclosing hyphae.

In conclusion, these ultrastructural changes of host tissues and fungal hyphae may reflect the pathogenesis of apple white rot under varying conditions of apple fruits. The structural differences were noted between mature and immature fruits as well as between susceptible and resistant responses, providing information on latency- and defense-related ultrastructural characteristics of apple fruit tissues and $B$. dothidea.

\section{ACKNOWLEDGMENTS}

This study was supported by the Korea Science and Engineering Foundation Project 961-0603-019-2. We thank E. M. Martin and S. C. Goeke for technical assistance in electron microscopy.

\section{LITERATURE CITED}

1. Brown, A. E. 1984. Relationship of endopolygalacturonase inhibitor activity to the rate of fungal rot development in apple fruits. Phytopathol. Z. 111:122-132.

2. Brown, E. A., and Hendrix, F. F. 1981. Pathogenicity and histopathology of Botryosphaeria dothidea on apple stems. Phytopathology 71:375-379.

3. Brown, M. F., and Wyllie, T. D. 1970. Ultrastructure of microsclerotia of Verticillium albo-atrum. Phytopathology 60:538-542.

4. Cromey, M. G., and Cole, A. L. J. 1985. Cytology of the host-pathogen interactions between Lolium perenne and Drechslera dictyoides. Plant Pathol. 34:83-94.

5. El-Ghaouth, A., Arul, J., Wilson, C., and Benhamou, N. 1994. Ultrastructural and cytochemical aspects of the effect of chitosan on decay of bell pepper fruit. Physiol. Mol. Plant Pathol. 44:4172-432.

6. El-Ghaouth, A., Wilson, C. L., and Wisniewski, M. 1998. Ultrastructural and cytochemical aspects of the biological control of Botrytis cinerea by Candida saitoana in apple fruit. Phytopathology 88:282-291.

7. Esau, K. 1965. Plant Anatomy, 2nd ed. John Wiley \& Sons, New York.

8. Garre, V., Tenberge, K. B., and Eising, R. 1998. Secretion of a fungal extracellular catalase by Claviceps purpurea during infection of rye: Putative role in pathogenicity and suppression of host defense. Phytopathology 88:744-753.

9. Guerin, L., Benhamou, N., and Rouxel, F. 1998. Ultrastructural and cytochemical investigations of pathogen development and host reactions in susceptible and partially-resistant carrot roots infected by Pythium violae, the major causal agent for cavity spot. Eur. J. Plant Pathol. 104:653-665.

10. Gunning, B. E. S., and Steer, M. W. 1996. Plant Cell Biology: Structure and Function. Jones and Bartlett Publishers, Sudbury.

11. Hong, Y. K., Yeh, W. H., Kim, C. H., Cho, E. K., and Lee, E. J. 1989. Etiology and histopathology of wart formation on apple caused by 
Botryosphaeria dothidea (Moug. ex Fr.) Ces. et \& de Not. (in Korean) Korean J. Plant Pathol. 5:151-160.

12. Hwang, B. K. 1983. Contents of sugars, fruit acids, amino acids and phenolic compounds of apple fruits in relation to their susceptibility to Botryosphaeria ribis. Phytopathol. Z. 108:1-11.

13. Kim, K. W., and Park, E. W. 1998. Production and exudation of Botryosphaeria dothidea conidia using cucumber disks and cereal media. (in Korean) Korean J. Plant Pathol. 14:46-51.

14. Kim, K. W., Park, E. W., and Ahn, K.-K. 1999. Pre-penetration behavior of Botryosphaeria dothidea on apple fruits. Plant Pathol. J. 15:223-227.

15. Kim, K. W., Park, E. W., Kim, S. B., and Yun, J. I. 1995. Temporal dynamics of Botryosphaeria dothidea spore dispersal in apple orchards and related climatological factors. (in Korean) Korean J. Plant Pathol. 11:230-237.

16. Kim, S. B., and Kim, C. S. 1989. Pathogenicity and ecology of apple rot caused by Botryosphaeria dothidea. III. The comparison to resistance against apple rot among several cultivars. (in Korean) J. Korean Soc. Hortic. Sci. 30:207-214.

17. Kohn, F. C., Jr., and Hendrix, F. F. 1983. Influence of sugar content and $\mathrm{pH}$ on development of white rot on apples. Plant Dis. 67:410-412.

18. Laborda, F., and Maxwell, D. P. 1976. Ultrastructural changes in Cladosporium cucumerinum during pathogenesis. Can. J. Microbiol. 22:394-403.

19. Lazarovits, G., and Higgins, V. J. 1976. Ultrastructure of susceptible, resistant, and immune reactions of tomato to races of Cladosporium fulvum. Can. J. Bot. 54:235-249.

20. Lim, L. L., Fineran, B. A., and Cole, A. L. J. 1983. Ultrastructure of intrahyphal hyphae of Glomus fasciculatum (Thaxter) Gerdemann and Trappe in roots of white clover (Trifolium repens L.). New Phytol. 95:231-239.

21. Maxwell, D. P., Armentrout, V. N., and Graves, L. B., Jr. 1977. Microbodies in plant pathogenic fungi. Annu. Rev. Phytopathol. 15:119-134.

22. McClendon, J. H., Somers, G. F., and Heuberger, J. W. 1960. The occurrence of a variety of enzymes hydrolyzing cell wall polysaccharides in apples rotted by Botryosphaeria ribis. Phytopathology 50:258-261.
23. McGlohon, N. E. 1982. Botryosphaeria dothidea-Where will it stop? Plant Dis. 66:1202-1203.

24. Murillo, I., Cavallarin, L., and San Segundo, B. 1999. Cytology of infection of maize seedlings by Fusarium moniliforme and immunolocalization of the pathogenesis-related PRms protein. Phytopathology 89:737-747.

25. Park, S. H., and Lee, C. U. 1993. Production of pectolytic enzymes and change of pectic substances from apple fruits infected with Botryosphaeria dothidea. (in Korean) Korean J. Mycol. 21:106-111.

26. Parker, K. C., and Sutton, T. B. 1993. Susceptibility of apple fruit to Botryosphaeria dothidea and isolate variation. Plant Dis. 77:385-389.

27. Powell, M. J. 1976. Ultrastructure and isolation of glyoxysomes (microbodies) in zoospores of the fungus Entophlyctis sp. Protoplasma 89:1-27.

28. Powell, M. J., and Roychoudhury, S. 1992. Ultrastructural organization of Rhizophlyctis harderi zoospores and redefinition of the type $1 \mathrm{mi}$ crobody-lipid globule complex. Can. J. Bot. 70:750-761.

29. Rayachhetry, M. B., Blakeslee, G. M., and Miller, T. 1996. Histopathology of Botryosphaeria ribis in Melaleuca quinquenervia: Pathogen invasion and host response. Int. J. Plant Sci. 157:219-227.

30. Seng, J. M., Saindrenan, P., and Bompeix, G. 1985. Induction of Nectria galligena mutants resistant to benzoic acid and study of their aggressiveness towards to immature apples. J. Gen. Microbiol. 131:1863-1866.

31. Shankar, M., Cowling, W. A., and Sweetingham, M. W. 1998. Histological observations of latent infection and tissue colonization by Diaporthe toxica in resistant and susceptible narrow-leafed lupins. Can. J. Bot. 76:1305-1316.

32. Sitterly, W. R., and Shay, J. R. 1960. Physiological factors affecting the onset of susceptibility of apple fruit to rotting by fungus pathogens. Phytopathology 50:91-93.

33. Sutton, T. B. 1990. White rot. Pages 16-18 in: Compendium of Apple and Pear Diseases. A. L. Jones and H. S. Aldwinckle, eds. The American Phytopathological Society, St. Paul, MN.

34. Sutton, T. B., and Arauz, L. F. 1981. Production and dispersal of conidia by Physalospora obtusa and Botryosphaeria dothidea in apple orchards. Phytopathology 71:584-589. 